\title{
Supporting Faculty to "Do the Flip!" Lessons Learned when Transitioning Faculty to Active Pedagogy in the Classroom
}

\section{Dr. Laura E. Sullivan-Green, San Jose State University}

Dr. Laura Sullivan-Green is an Associate Professor and Department Chair in the Civil and Environmental Engineering Department at San José State University. She obtained her BS from the University of Dayton (Dayton, OH) in 2002 and her MS (2005) and PhD (2008) from Northwestern University (Evanston, IL). She teaches in the areas of Geotechnical Engineering, Engineering Mechanics, and Forensic Engineering. Her research interests include evaluating crack age in construction materials, forensic engineering education, and STEM education pedagogy. She serves on the SJSU Academic Senate as the chair of the Instruction and Student Affairs committee and the Forensic Engineering Division of the American Society of Civil Engineers. Laura is the PI for the Department of Education's First in the World Grant awarded to San José State University, in partnership with Cal Poly Pomona and California State University- Los Angeles.

\section{Dr. Patricia R. Backer, San Jose State University}

Dr. Backer been a faculty at SJSU since 1990 and held positions as an assistant professor, associate professor, professor, department chair, and director. Since coming to San Jose State University in 1990, I have been involved in the General Education program. Currently, Dr. Backer serves as the PI for the Title III Strengthening grant both from the U.S. Department of Education.

\section{Dr. Ravisha Mathur, San Jose State University}

Ravisha Mathur is a faculty member in the Connie L. Lurie College of Education at San José State University. She has been active in working on instructional pedagogy in her classrooms for over 10 years. She has been teaching online for five years and reviewing online courses with the Quality Matters (QM) organization and in 2015 she transitioned to become a master reviewer. Currently, she is a QM Team Leader for the university and the Faculty Learning Community coordinator for the First in the World Program Grant. 


\title{
Evidence Based Practice: Supporting Faculty to "Do the Flip"! Lessons Learned when Transitioning Faculty to Active Pedagogy in the Classroom
}

\begin{abstract}
This paper is an Evidence Based Practice paper. The project focuses on an active and intuitive learning technique, flipped classroom. In this technique, the usual student- teacher centered lecture is replaced by a more student driven approach where a student prepares prior to a class, which gives more time for in class discussions and problem solving. This project is a combined effort from three universities: San José State University (SJSU), California State University-Los Angeles (CSULA), and Cal Poly Pomona (CPP). This project aims to improve retention rates in STEM courses thereby increasing the number of students who graduate with STEM degrees. The three universities belong to the CSU system which is the largest university system in the entire country. The program is funded by the U.S Department of Education under the First in the World program. The outcome of this project is to check if the flipped teaching style helps in reducing the failure rates of students in gateway STEM courses. The authors prefer a lightening session.
\end{abstract}

\section{Background}

The grant was funded by the U.S Department of Education under its First in the World program. The activities in the Grant were inspired by the recognition that URM students had lower rates of success in key undergraduate STEM courses. Each new generation has its own challenges. Although lecture-based classes may have worked in the past, they are no longer adequate [1]. Universities must acknowledge this and take steps to adjust pedagogy accordingly. A seminal report published by the National Research Council in 1999, How People Learn: Brain, Mind, Experience and School [2], includes a call for a university culture where a deep understanding of how students learn determines both the content of the curriculum and how it is taught. Instead of the classroom being the sole source of learning, faculty should function as learning guides. The Model Institutions for Excellence (MIE) program, funded by the NSF and NASA over 11 years, included student learning communities, small group learning, and faculty development to increase URM student enrollment in STEM fields. This work led to increased STEM enrollments of URM students [3][4] and increased degrees conferred on URM students in STEM fields [5].

There is a national need to broaden the participation of women and underrepresented minority (URM) students in science and engineering [6]. The lack of trained scientists and engineers from diverse ethnic backgrounds is noted by the National Academy of Sciences as a barrier for the in global competitiveness [7].

\section{Demographics}

All three of these institutions are Hispanic-serving institutions. The demographics of the undergraduates at these three universities is shown in Table 1. There are more than 32,000 undergraduate and graduate students in SJSU across its seven colleges. The college offers 
bachelors, masters and doctorate programs. CPP is one of the only seven polytechnic universities in the nation. It has 24,000 students across the 8 colleges offering more than 100 courses in leading to bachelors, masters and doctoral degrees.

Table 1. Distribution of Undergraduates by Ethnicity at the Three Universities

\begin{tabular}{|l|l|l|l|l|l|l|}
\hline & \multicolumn{2}{|c|}{ SJSU } & \multicolumn{2}{c|}{ CSULA } & \multicolumn{2}{c|}{ CPP } \\
\hline & Headcount & percent & Headcount & percent & Headcount & percent \\
\hline African American & 899 & $3.30 \%$ & 788 & $3.30 \%$ & 777 & $3 \%$ \\
\hline American Indian & 21 & $0.07 \%$ & 14 & $0.10 \%$ & 52 & $0.20 \%$ \\
\hline Asian & 9,821 & $35.90 \%$ & 3,105 & $12.90 \%$ & 5697 & $22 \%$ \\
\hline Hispanic & 7,755 & $28.30 \%$ & 16,239 & $67.70 \%$ & 11,134 & $43 \%$ \\
\hline Pacific Islander & 131 & $0.40 \%$ & 23 & $0.10 \%$ & 52 & $0.20 \%$ \\
\hline White & 4,108 & $15 \%$ & 1,192 & $5 \%$ & 4402 & $17 \%$ \\
\hline Foreign & 2,213 & $8.10 \%$ & 1,719 & $7.20 \%$ & & \\
\hline Two or more/other & 2,379 & $8.70 \%$ & 922 & $3.80 \%$ & 3625 & $14 \%$ \\
\hline Total & 27,327 & & 24,002 & & 24,314 & \\
\hline
\end{tabular}

CSULA has eight colleges and is home to one of the most diverse student population in the nation. The college has around 24,000 undergraduate students alone with majority being from the Hispanic community. At each university, there are many students who are either first generation, under- represented minorities (URM) or/and low-income students. $64 \%$ of SJSU students, $80.8 \%$ of CSULA students, and $66 \%$ of CPP students qualify for financial aid in the form of grants, scholarships, loans. $38 \%$ of SJSU students, $75 \%$ of CSULA students, and $45 \%$ of Cal Poly Pomona students receive PELL grants.

This grant included seven core classes at the three institutions: Calculus I, Physics I and II, Statics, Circuits, Intro to Programming, and Discrete Mathematics. We opened the summer 2017 and 2018 flipped workshops to undergraduate STEM faculty at the three universities. Most of the faculty implemented flipped instruction in the lecture portion of their courses. As the three universities are CSUs, our class sizes typically range from 25 to 75 . Physics I flipped the laboratory portion of the course. The instructor developed pre-lab example problems and lab presentations which the students did before the lab. When the students went to their lab sections, they participated in workshop-type activities where they solved problems, performed lab activities and participated in discussion sessions. The individual lesson plans are available on the project website at http://www.sjsu.edu/firstintheworld/.

\section{Faculty Survey on Active Learning}

Despite increasing research on active learning, the teacher-centered lecture model still persists in STEM fields [8]. Although the number of faculty using active learning (or student centered) methods has increased in the last ten years, the Higher Education Research Institute survey of faculty in 2013 showed that half (50.6\%) of faculty use a lectured-based classroom instead of active learning [9].

"Active learning is generally defined as any instructional method that engages students in the learning process. In short, active learning requires students to do meaningful learning activities and think about what they are doing. The core elements of active learning are 
student activity and engagement in the learning process" [10].

The number of engineering faculty using active learning is lower than other fields: a national survey of engineering faculty [11] found that only $47 \%$ of engineering professors use active learning in their classrooms. Indeed, Lord and Camacho [12] found that most teachingoriented engineering faculty know there are problems with lecture-based instruction; yet $60 \%$ of them still teach that way.

Integrating active learning techniques into STEM classes has produced gains in student learning. A study completed by Hake [13] in Physics showed that when active engagement methods were used, students' scores on a Force Concept Inventory (FCI) were higher than students in traditional classrooms. At Purdue University, large STEM lecture courses were redesigned to include active learning strategies in STEM classes; this is part of the Purdue Academic Course Transformation program (IMPACT) [14]. As a result of IMPACT, overall student retention increased by $1 \%$, while retention in their respective STEM courses increased by $2 \%$. After the redesign, student GPAs of those taking IMPACT made a significant increase, making a significant difference between Non-IMPACT and IMPACT classes. Improved learning and improved student achievement in active learning STEM classrooms also has been documented by Deslauriers et al [15], Prince [16], Beichner [17], and Michael [18].

To gather a baseline for our efforts, we surveyed the faculty at all three universities about the flipping methodology. Over 900 STEM faculty at the three campuses involved in the FITW project were offered a survey about their knowledge of, and experiences with, flipped instruction. Here we report on the results of the 18 item survey, completed by 333 STEM faculty (more than 100 at each campus). Some questions were demographic, to gain information about teaching experience and gender.

Most items were about faculty perceptions of the potential benefits of, or challenges to, flipping. A few open-ended items solicited further details about particular aspects of faculty views on flipped learning. Among those completing the survey, $66 \%$ were tenured $(46 \%)$ or tenure-track $(22 \%)$, about the rest were adjuncts or lecturers $(30 \%)$ or people with other instructional roles (4\%; e.g., teaching assistants, coaches, emeritus instructors). Half of respondents characterized their STEM field as science. Engineering was identified by $31 \%$ of respondents, while 25\% selected math. Only $7 \%$ identified their field as technology. The key findings are shown below.

- More than $66 \%$ of respondents were familiar with and had tried problem---based learning or collaborative learning in their classes.

- Among the 333 respondents, 66\% said they had not yet tried flipping a class with one--third reporting already trying a flip of some kind.

- More than $66 \%$ who had tried flipping rated it as a positive experience.

- Most respondents who had tried flipping did so in classes of 60 or fewer students.

- $60 \%$ of the respondents rated student---centered learning as the greatest potential benefit for instruction in flipped courses, with improved learning environment a close second. 
- Among those who had tried flipping, 66\% agreed that students are more engaged in a flipped learning environment.

- $55 \%$ of the respondents rated time as a challenge to flipping. In open ended questions, time was the leading factor when respondents were asked what additional support they needed to flip their courses; many also identified money for time and resources as a significant need.

In the survey, we asked the faculty about the potential benefits of flipped classroom instruction. Of the 333 faculty who responded to the survey, 288 answered this question. The highest ranked benefits were more learner-centered teaching (65\%), improved learning environment (54\%), instructor gets to know students better (47\%, and (it) re-energizes a course (46\%). All of the responses are shown in Figure 1.

Figure 1. FITW Survey Results: What do you see as the potential benefits for flipped classroom instruction?

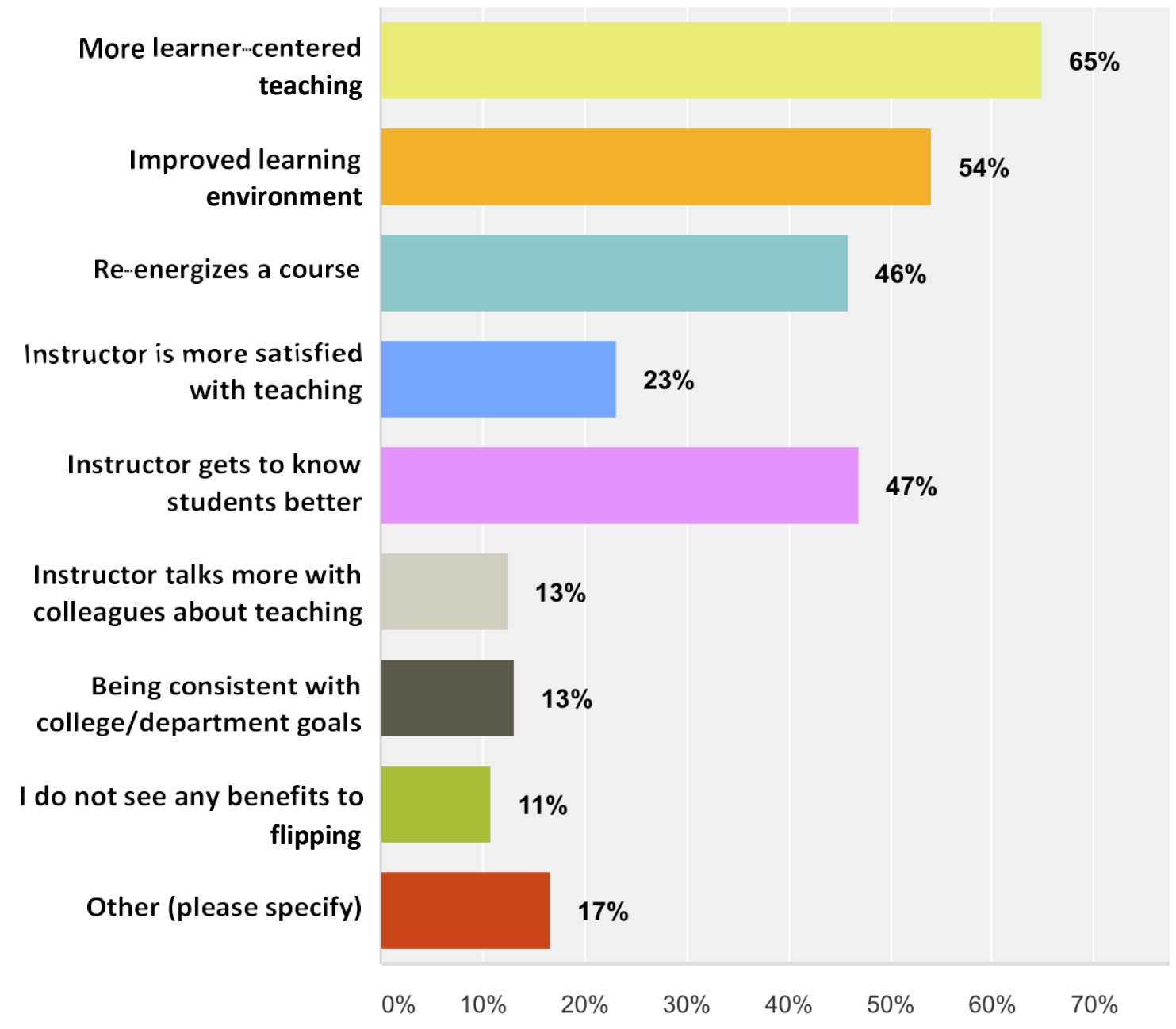

Through our work on this grant, we have seen faculty encounter many challenges. These challenges align with a national survey of faculty [19] and our own survey (see Table 2). 280 survey takers responded to this question. Responses were similar to those in the 
national survey with two interesting exceptions: (1) though about half of FITW respondents said time was a challenge, nearly three---quarters on the national survey did and (2) FITW respondents appeared to have more confidence in students taking up the ideas (i.e., a lower percentage identified student resistance as a challenge).

Table 2. Challenges in Implementing Flipping in a STEM Course, Comparison of FITW Survey and National Survey [19]

\begin{tabular}{|l|c|c|}
\hline Challenge & National Survey Results & FITW Survey Results \\
\hline Time & $70 \%$ & $53 \%$ \\
\hline Material support/resources & $39 \%$ & $46 \%$ \\
\hline Student resistance/lack of motivation & $45 \%$ & $31 \%$ \\
\hline Developing new strategies and ideas & $45 \%$ & $41 \%$ \\
\hline
\end{tabular}

Community of Inquiry Framework

The foundation for this curricular development is based on the Community of Inquiry (CoI) framework [20]. The CoI framework has three parts: social presence, cognitive presence and teaching presence. The indicators of social presence are open communication among participants, individuals identifying with the group, and the development of strong interpersonal relationships among the members of the group. Cognitive presence is the process in which the participants learn how to approach new pedagogies (in our case, the flipped learning pedagogy), deepen their understanding of the pedagogy, and apply it to their own learning spaces. Creating a teaching presence includes creating an enhanced learning experience for students to learn the course material with the support and guidance of the instructor.

Activities and materials were created following the CoI framework; these materials have been developed and tested across all three campuses. On each campus, there is a Faculty Learning Community (FLC) which supports the faculty who are involved in implementing the flipped classroom model into their classes. In addition, we have disciplinary FLCs that engage faculty from all three campuses. For example, the Calculus I faculty on all three campuses have collaborated on developing materials for their flipped classrooms.

Faculty development was based on social cognition model. "Social cognition models tend to emphasize discussion and learning among institutional participants, helping them to understand the change process" [21]. Change is not linear; it "is a multifaceted, interconnected, overlapping series of processes, obstacles and individuals" [22]. The metaphor for change is based on brain research and includes complex and interrelated systems, mental models, and interpretation of new situations. A key to this model is sensemaking - a process of making sense out of change and ambiguity in the educational environment [23]. The faculty in this project will work together in teams, through FLCs, to formulate new conceptualizations of teaching in the university.

According to the theory of change model [24], interdisciplinary teams facilitate discussions about beliefs and assumptions because faculty typically work in silos and are not asked why they hold particular beliefs or embrace particular techniques of teaching [25]. Reports have 
indicated the need for curricular reforms to provide undergraduate education that engages student and teachers invoking a sense of deep learning.

In Summer 2016, there was a training for core faculty from all the three campuses in the form of a three-day intensive faculty summer workshop. In Summer 2017, an additional 58 faculty members were trained at the three campuses and 48 faculty were trained in Summer 2018. This training was to expose the faculty to the CoI framework- to discuss various effective pedagogical practices for URM students, strategies to encourage students to have a deeper understanding of subjects, role of faculty in bringing about this positive change in students, use of flipped approach to engage wide variety of learners. In this workshop each of the core faculty met with the PI and the campus lead to discuss and obtain inputs on project goals, respective timelines and responsibilities for the academic semester.

During these workshops, faculty have their own flipped learning to do as part of this. They have to come prepared with their game plan using the materials provided to them. The faculty are given a book called Flipped Learning by Robert Talbert as pre-workshop reading. At the end of the workshop, the faculty are expected to have their lesson plan ready to present in front of a faculty panel who will approve the same. This panel provided guidance and future support for the faculty in charge of flipped learning. Figure 2 displays the agenda for the one-day training workshops in 2017 and 2018.

Figure 2. Agenda for the Do the Flip! Summer Workshops

\begin{tabular}{|c|c|}
\hline & Do the Flip! Summer Workshops Activity \\
\hline Time & Activity \\
\hline $8: 15-8: 30$ & Welcome! Coffee, Continental Breakfast, Paperwork \\
\hline $8: 30-8: 45$ & Introductions + Chalk Talk \\
\hline $8: 45-9: 30$ & $\begin{array}{l}\text { What's in a Lesson Plan? -Lesson Plan Components, Compare } \\
\text { exemplary and ineffective flipped class lesson plans }\end{array}$ \\
\hline $9: 30-10: 30$ & $\begin{array}{l}\text { Learning objectives in the Flipped Class - Clarify basic and } \\
\text { advanced LO's with collegial feedback }\end{array}$ \\
\hline 10:30-10:45 & Break \\
\hline 10:45- 12:00 & $\begin{array}{l}\text { Active Learning Strategies - Individual vs group space activities - } \\
\text { Tying activities to Bloom's taxonomy and specific course objectives } \\
\text { ( SJSU eCampus programs and Resources ) }\end{array}$ \\
\hline 12:00-12:45 & Lunch \\
\hline $12: 45-1: 15$ & $\begin{array}{l}\text { Planning Individual Space Activities - Draft a plan for pre- meeting } \\
\text { individual space activities for your lesson }\end{array}$ \\
\hline $1: 15-2: 15$ & $\begin{array}{l}\text { Planning the Group Space and Post Lesson Agenda - Draft a plan } \\
\text { for the group space agenda for your lesson - Draft a plan for post } \\
\text { meeting individual space activities for your lesson }\end{array}$ \\
\hline $2: 15-2: 30$ & Break \\
\hline $2: 30-3: 00$ & $\begin{array}{l}\text { Student Motivation \& Preparation - How do you get the students to } \\
\text { do the individual space work? }\end{array}$ \\
\hline $3: 00-3: 45$ & $\begin{array}{l}\text { Q\&A with Flipped Out Faculty - What is the student response to the } \\
\text { Flip? Biggest challenge and solution? Best thing about the Flip? }\end{array}$ \\
\hline
\end{tabular}


After the workshop - What to do for the advanced practice individual space activity

In addition to the pre-workshop activities and the one-day workshop activities, the faculty were asked to complete post workshop activities (see Figure 3). Faculty who completed these activities successfully received a $\$ 250$ stipend and were eligible for funding in a subsequent year.

Figure 3. Post-workshop Activities Given to the Participants

- A completed lesson plan for at least one lesson in your target class, that has been revised following feedback from one of your workshop colleagues (partners will be paired up in the workshop)

- A "guided practice" document for the lesson, again revised according to collegial feedback (note that there will be some overlap between the lesson plan and the guided practice. The lesson plan is for your use; guided plan is for student's use.)

- A brief reflection about what, if anything, you plan to do for flipping a class in Fall 20XX. Note you don't actually have to flip anything, but we hope you do! Comment on the time, energy, etc and if you are planning to flip, describe how you plan to get those resources.

Lessons Learned

During the course of this flipped learning initiative, it was imperative for faculty to realize that the pilot program they were testing might not result in immediate success. It calls for patience with the students as students need time to get used to the new system of instruction. However, results show that this program in fact has benefitted students and their performance is better. As a result, the "slump" was avoided which usually affects the student's performance as a result of new teaching methods being implemented. The joint collaboration and support given by the FLCs plays a vital role because they help the faculty to think outside the box and come up with innovative coursework for flipped learning. The coordinators along with the panel approve the coursework that the core faculty come up with.

The flipped learning program has been successfully implemented across three campuses in the CSU system. This program was conducted over a period of three years. There was a continuous improvement process with respect to the materials developed for the flipped learning curriculum. This has enabled students to think outside the box and have a more analytical approach towards different problems. There have been regular performance reviews to see how effective the program was. Based on the results, respective changes to meet all the requirements took place.

\section{References}

[1] Kember, D. (2009). Promoting student-centered forms of learning across an entire university. Higher 
[2] The National Academies Press (2000). How People Learn: Brain, Mind, Experience, and School: Expanded Edition. Washington, DC: The National Academies Press.

[3] Kim, J.J., Crasco, L.M., Leavitt, D.J., \& Milchunes, B.E. (2007). MIE Fact Book 2005. Norwood, MA: Systemic Research, Inc. http://www.systemic.com/Publication/.

[4] Rodriguez, C., Rita, K., \& Hale, M. (2005). Creating and Maintaining Excellence: The Model Institutions for Excellence Program. Washington, DC: American Institutes for Research (AIR). http://www.air.org/publications/documents/MIE Report final.pdf.

[5] Institute for Higher Education Policy (IHEP) (2007). A Model for Success: The Model Institutions for Excellence Program's Successful Leadership in STEM Education. Washington, DC: IHEP. http://www.ihep.org/Publications/publications-detail.cfm?id=53.

[6] Lewis, J. L., Menzies, H., Nájera, E. I., \& Page, R. N. (2009). Rethinking trends in minority participation in the sciences. Science Education, 93(6), 961-977; National Science and Technology Council (2000). Ensuring a strong U.S. scientific, technical, and engineering workforce in the 21 st century. http://www.nsf.gov/nsb/documents/2003/nsb0369/nsb0369.pdf.

[7] National Academy of Sciences. (2007). Rising above the gathering storm: Energizing and employing America for a brighter future. Available: http://www.nap.edu/catalog/11463html

[8] Kardash, C. M., \& Wallace, M. L. (2001). The perceptions of science classes survey: What undergraduate science reform efforts really need to address. Journal of Educational Psychology, 93, 199-210 AND Walczyk, J. L. \& Ramsey, L. L. (2003). Use of learner-centered instruction in college science and mathematics classrooms. Journal of Research in Science Teaching, 40(6), 566-584 AND Seymour, E., \& Hewitt, N. M. (2000). Talking about leaving: Why undergraduates leave the sciences. Boulder, CO: Westview Press AND National Governors Association Center for Best Practices. Building a science, technology, engineering and math education agenda: an update of state actions. Washington, DC: National Governors Association Center for Best Practices; 2012.

[9] Eagan, M. K., Stolzenberg, E. B., Berdan Lozano, J., Aragon, M. C., Suchard, M. R. \& Hurtado, S. (2014). Undergraduate teaching faculty: The 2013-2014 HERI Faculty Survey. Los Angeles: Higher Education Research Institute, UCLA. Available: http://www.heri.ucla.edu/monographs/HERI-FAC2014monograph.pdf

[10] Prince, M. (2004). Does active learning work? A review of the literature. Journal of Engineering Education, 93(3), 223-231.

[11] Borrego, M., Froyd, J. E., \& Hall, T. S. (2010, July). Diffusion of engineering education innovations: A survey of awareness and adoption rates in U.S. engineering departments. Journal of Engineering Education, pp. 185-207.

[12] Lord S, \& Camacho, M. (2007). Effective teaching practices: preliminary analysis of engineering educators. Paper presented at: Proceedings of the 37th ASEE/IEEE Frontiers in Education Conference; 2007 Oct 10-3; Milwaukee, WI.

[13] Hake, R. (1998, January). Interactive-engagement vs traditional methods: A six-thousand-student survey of mechanics test data for introductory physics courses, Amer. J. Phys.,66, pp. 64-74, Jan. 1998.

[14] Purdue Impact. Funded by 2014 DoE FITW. Available: http://www.purdue.edu/impact/

[15] Deslauriers, L., Schelew, E., \& Wieman, C. (2011, May 13). Improved learning in a large-enrollment physics class, Science, 332, pp. 862-864.

[16] Prince, M. (2004, July). Does active learning work? A review of the research, J. Eng. Educ., 93, pp. 223223.

[17] Beichner, R. (2008, September). The SCALE-UP project: A student-centered, active learning environment for undergraduate programs, invited white paper for the National Academy of Sciences, Sep. 2008.

[18] Michael, J. (2006, December). Where's the evidence that active learning works?,” Adv.Physiol. Educ., 30, pp. $159-167$.

[19] Faculty Focus (2015). Flipped classroom trends: A survey of college faculty. Madison, WI: Magna Publications.

[20] Garrison, D. R., \& Vaughan, N. (2008). Blended Learning in Higher Education: Framework, Principles, and Guidelines. San Fransisco: Jossey-Bass.

[21] Kezar, A. J. (2011). Understanding and facilitating organizational change in the 21 st century. ASHE-ERIC Higher Education Report, 28(4).

[22] Kezar, Op cit, p. 45

[23] Weick, K. (1995). Sensemaking in Organisations. London: Sage AND Weick, K., Sutcliffe, K. M., \& 
Obstfeld, D. (2005). Organizing and the process of sensemaking. Organization Science, 16(4): 409-421

[24] Eckel, P. D. \& Kezar, A. J. (2003). Taking the Reins: Institutional Transformation in Higher Education. Greenwood Publishing Group

[25] Gioia, D., Thomas, J., Clark, S. \& Chittipeddi, K. (1996). Symbolism and strategic change in academia: The dynamics of sensemaking and influence. Organization Science, 5(3), 363-383. 
1 Kember, D. (2009). Promoting student-centered forms of learning across an entire university. Higher Education, 58, 1-13.

2 The National Academies Press (2000). How People Learn: Brain, Mind, Experience, and School: Expanded Edition. Washington, DC: The National Academies Press.

3 Kim, J.J., Crasco, L.M., Leavitt, D.J., \& Milchunes, B.E. (2007). MIE Fact Book 2005. Norwood, MA: Systemic Research, Inc. http://www.systemic.com/Publication/.

4 Rodriguez, C., Rita, K., \& Hale, M. (2005). Creating and Maintaining Excellence: The Model Institutions for Excellence Program. Washington, DC: American Institutes for Research (AIR). http://www.air.org/publications/documents/MIE_Report_final.pdf.

$5 \quad$ Institute for Higher Education Policy (IHEP) (2007). A Model for Success: The Model Institutions for Excellence Program's Successful Leadership in STEM Education. Washington, DC: IHEP. http://www.ihep.org/Publications/publications-detail.cfm?id=53.

6 Lewis, J. L., Menzies, H., Nájera, E. I., \& Page, R. N. (2009). Rethinking trends in minority participation in the sciences. Science Education, 93(6), 961-977; National Science and Technology Council(2000).

Ensuring a strong U.S. scientific, technical, and engineering workforce in the 21st century. http://www.nsf.gov/nsb/documents/2003/nsb0369/nsb0369.pdf.

$7 \quad$ National Academy of Sciences. (2007). Rising above the gathering storm: Energizing and employing America for a brighter future. Available: http://www.nap.edu/catalog/11463html

8 Kardash, C. M., \& Wallace, M. L. (2001). The perceptions of science classes survey: What undergraduate science reform efforts really need to address. Journal of Educational Psychology, 93, 199-210 AND Walczyk, J. L. \& Ramsey, L. L. (2003). Use of learner-centered instruction in college science and mathematics classrooms. Journal of Research in Science Teaching, 40(6), 566-584 AND Seymour, E., \& Hewitt, N. M. (2000). Talking about leaving: Why undergraduates leave the sciences. Boulder, CO: Westview Press AND National Governors Association Center for Best Practices. Building a science, technology, engineering and math education agenda: an update of state actions. Washington, DC: National Governors Association Center for Best Practices; 2012.

9 Eagan, M. K., Stolzenberg, E. B., Berdan Lozano, J., Aragon, M. C., Suchard, M. R. \& Hurtado, S. (2014). Undergraduate teaching faculty: The 2013-2014 HERI Faculty Survey. Los Angeles: Higher Education Research Institute, UCLA. Available: http://www.heri.ucla.edu/monographs/HERIFAC2014- monograph.pdf

10 Prince, M. (2004). Does active learning work? A review of the literature. Journal of Engineering Education, 93(3), 223-231.

11 Borrego, M., Froyd, J. E., \& Hall, T. S. (2010, July). Diffusion of engineering education innovations: A survey of awareness and adoption rates in U.S. engineering departments. Journal of Engineering Education, pp. 185-207.

12 Lord S, \& Camacho, M. (2007). Effective teaching practices: preliminary analysis of engineering educators. Paper presented at: Proceedings of the 37th ASEE/IEEE Frontiers in Education Conference; 2007 Oct 10-3; Milwaukee, WI.

13 Hake, R. (1998, January). Interactive-engagement vs traditional methods: A six-thousand-student survey of mechanics test data for introductory physics courses, Amer. J. Phys., 66, pp. 64-74, Jan. 1998. Purdue Impact. Funded by 2014 DoE FITW. Available: http://www.purdue.edu/impact/

15 Deslauriers, L., Schelew, E., \& Wieman, C. (2011, May 13). Improved learning in a largeenrollment physics class, Science, 332, pp. 862-864.

16 Prince, M. (2004, July). Does active learning work? A review of the research, J. Eng. Educ., 93, pp. $223-223$.

17 Beichner, R. (2008, September). The SCALE-UP project: A student-centered, active learning environment for undergraduate programs, invited white paper for the National Academy of Sciences, Sep. 2008.

18 Michael, J. (2006, December). Where's the evidence that active learning works?," Adv.Physiol. Educ., 30, pp. $159-167$.

19 Faculty Focus (2015). Flipped classroom trends: A survey of college faculty. Madison, WI: 
Magna Publications.

20 Garrison, D. R., \& Vaughan, N. (2008). Blended Learning in Higher Education: Framework, Principles, and Guidelines. San Fransisco: Jossey-Bass.

21 Kezar, A. J. (2011). Understanding and facilitating organizational change in the 21st century. ASHEERIC Higher Education Report, 28(4).

22 Kezar, Op cit, p. 45

23 Weick, K. (1995). Sensemaking in Organisations. London: Sage AND Weick, K., Sutcliffe, K. M., $\&$ Obstfeld, D. (2005). Organizing and the process of sensemaking. Organization Science, 16(4): 409-421

24 Eckel, P. D. \& Kezar, A. J. (2003). Taking the Reins: Institutional Transformation in Higher Education. Greenwood Publishing Group

25 Gioia, D., Thomas, J., Clark, S. \& Chittipeddi, K. (1996). Symbolism and strategic change in academia: The dynamics of sensemaking and influence. Organization Science, 5(3), 363-383. 